\title{
The Recession's Impact on the State Budgets of New York and New Jersey
}

\author{
Richard Deitz, Andrew F. Haughwout, and Charles Steindel
}

\begin{abstract}
In the wake of the most recent U.S. recession, both New York State and New Jersey have faced multibillion-dollar budget gaps. An analysis of the makeup of their budgets reveals that the states' heavy reliance on personal income taxes-particularly from highwage earners in the finance sector-has exacerbated revenue shortfalls. To close their budget gaps, New York and New Jersey have had to make difficult choices about tax increases and service cuts. In the future, the states might take steps to avert such budget quandaries by establishing "rainy day" funds or restructuring taxes to make them less sensitive to the business cycle.
\end{abstract}

$\mathrm{H}$ ouseholds and businesses were not alone in feeling the strain of the 2007-09 recession. ${ }^{1}$ The economic downturn has put considerable stress on the budgets of state and local governments as well. Declines in employment, income, and business activity have translated into lower tax revenues. Meanwhile, the need for government support, including unemployment benefits and other forms of social assistance, has increased. As a result, many state governments have large budget gaps and are facing difficult choices in how to close them (Gerst and Wilson 2010).

This fiscal stress has been particularly acute in states that have relied heavily on tax revenues from economic sectors hit hard by the recession. New York State and New Jersey are cases in point: Throughout much of the 1990s and 2000s, both states depended on the financial industry to supply a large and rapidly growing share of revenues. As the financial crisis took hold, however, tax revenues from this industry dropped rapidly, contributing to the emergence of large budget holes in both states. New York's fiscal year 2010 budget gap — the difference between anticipated revenues and previously planned expenditures-was as large as $\$ 16$ billion when the state budget was being prepared in early 2009, representing roughly 30 percent of the budget under discussion. For New Jersey, reports cited a gap of $\$ 9$ billion, or roughly 25 percent. $^{2}$ In early 2010 , both states were again confronting multibillion-dollar gaps as they prepared their budgets for the 2011 fiscal year.

Second District Highlights

In this issue of Second District Highlights, we provide an overview of the budget process in New York and New Jersey and explore why the recession has taken such a toll on the states' fiscal condition. We begin by reviewing some general principles of

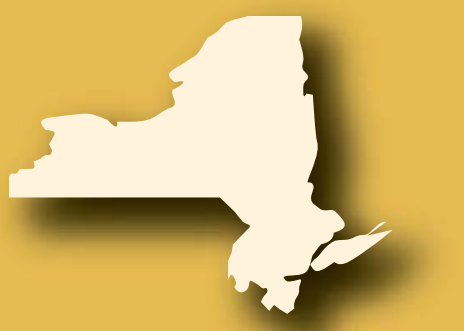

1 The National Bureau of Economic Research determined that the peak in U.S. economic activity occurred in December 2007 (see http://www.nber.org/cycles/dec2008.pdf). It may declare a month in mid-2009 as the trough of the business cycle.

${ }^{2}$ Recent actions, including large increases in federal aid, helped close an estimated aggregate gap of $\$ 162.5$ billion in states' fiscal 2010 budgets, according to the Center on Budget and Policy Priorities (CBPP). Nonetheless, significant budget strains are expected in the years ahead. The CBPP reported in May 2010 that states were already anticipating at least $\$ 112$ billion in additional gaps for the 2011 fiscal year. See McNichol and Johnson (2010). 
state government finance and then take a closer look at the specific revenue sources and expenditures of New York and New Jersey and the rules that govern the two states' budgets. We also consider the steps that state officials have taken to close emerging gaps in their budgets — both recently and in the past.

Our overview of the New York and New Jersey budgets sheds light on the genesis of the states' current fiscal difficulties. We suggest that the revenue structure of the two states has helped to create the potential for recessions to produce severe and sustained financing problems. Specifically, both states' heavy reliance on personal income taxes has made their revenue streams especially vulnerable to economic downturns. The wage reductions, layoffs, and capital losses that accompanied the most recent recession - and that were particularly severe in the finance industry so central to the New York and New Jersey economieshave sharply reduced these tax inflows. Moreover, the budget rules in the two states - most notably New York's fairly lenient budget balance rule and the constraints affecting New Jersey's allocation of tax revenues across different needs-may make it more difficult to deal with rising economic pressures.

In the article's concluding section, we consider some of the policy options that might help state officials avert enormous budget shortfalls during future economic declines. New York and New Jersey could diversify their economies away from finance, create reserve funds that would provide a buffer against economic shocks, raise more revenue from sources less volatile than personal income taxes, or commit to imposing temporary tax increases on high-income households during downturns. As our discussion makes clear, however, all of these measures pose challenges of their own.

\section{State Budget Rules}

In principle, state governments are required to have annual balanced budgets (Vermont is the only exception). In practice, however, this requirement is fairly elastic. Normally, only the operating budget (often referred to as the "general budget," although states use different names) is required to balance, while state and local governments typically raise and disburse funds outside of this sphere.

For example, capital budgets, which encompass funds for public construction and transportation infrastructure, and employee pension funds are not part of operating budgets and are not usually required to balance every year. Indeed, in the case of capital budgets, financing frequently takes the form of long-term debt issuance, while pension funds can run surpluses in anticipation of future payments to retired employees. In addition, state disbursements funded by the federal government are often omitted from operating budget expenditures, and federal payments are not counted in operating budget receipts.

The requirement for balanced budgets is designed to keep state governments from borrowing to fund their current opera- tions. This treatment guarantees that the cost of goods and services fully used in the short run - such as health care servicescannot be passed on to future taxpayers through longer-term financing. By contrast, public goods and services used over an extended period - for example, roads and infrastructure—could appropriately be funded over time because their benefits are realized by generations of users. ${ }^{3}$ Of course, formal balanced-budget regulations are not the only curb on excessive borrowing by state governments. The cost of financing debt in the bond market has a similar effect: When states try to borrow too much, they may be perceived as a risky bet by bondholders; consequently, they are likely to see the credit ratings on their bonds decline while their interest charges rise.

The particular rules that states must follow in balancing their budgets vary across the country. In some states, the only requirement is that the governor submit a budget that is prospectively balanced - that is, a budget in which projected revenues match or exceed projected expenditures. In other states, the legislature is required to pass a balanced budget. The most stringent rule in effect among the states is a prohibition against carrying a deficit into the next fiscal year (meaning that a portion of next year's revenues will be used to pay this year's deficit). This rule is included in the constitutions of some states and enforced by their state supreme courts. The variations in rules can have large effects on budgetary outcomes, and states with stricter requirements tend to have larger and more frequent surpluses. ${ }^{4}$

By these measures, New Jersey's balanced-budget requirements are fairly rigorous. The state constitution requires enactment of a prospectively balanced budget and prohibits any carrying over of deficits from one fiscal year to the next. In contrast, New York's constitution is fairly lenient in this area, requiring only that the governor submit a balanced budget. In a 1987 rating of states' balanced-budget stringency on a scale of one to ten (with ten being the most stringent), New Jersey received a ten and New York a three (Advisory Commission on Intergovernmental Relations 1987).

In addition to preparing a balanced budget at the start of the fiscal year, states typically need to monitor their budgets during the year to determine whether revenues and expenditures remain in balance. Since the recession began, many states have found themselves facing large intra-year deficits as projected inflows fall markedly short of projected expenditures. The budget rules in most states call for some corrective action to deal with such

\footnotetext{
${ }^{3}$ This treatment is in contrast to the way the federal budget is balanced. The most widely reported measure of federal budget balance is the difference between receipts and expenditures, as reflected in the cash payments that occur during a federal fiscal year. In federal government accounting, no distinction is typically made between spending on long-lived capital goods and spending on operating expenditures.

${ }^{4}$ Bohn and Inman (1996) show that a prohibition against deficit carryover, for example, increases state surpluses by approximately $\$ 100$ per resident; they also find that "constraints which only require governors to submit or the legislature to pass a balanced budget are at best weak inducements to fiscal discipline" (p. 42).
} 
prospective budget gaps. Certain states require an aggressive response-New Jersey, for example, must close any emerging deficit to avoid carrying it over to the next fiscal year.

\section{How a Recession Affects State Budgets}

Recessions create budget pressures because they tend to slow the growth of revenues while creating a need for higher spending in a number of areas.

\section{Impact on Revenues}

How a recession affects a state's revenues depends on the particular mix of revenue sources used by the state and the response of these sources to deteriorating economic conditions. All states, however, are likely to see some decline in revenue growth, which in turn may affect not only their income streams in the short run, but also their ability to raise revenues for years to come.

A state's tax revenues come from some combination of four main sources: individual income tax, corporate income tax, general sales tax, and various other taxes. During the 2007-09 recession, the national numbers show that all sources of state tax revenue fell on a year-over-year basis, a phenomenon not seen since the 1980s (Chart 1). ${ }^{5}$ Revenues from personal income taxes and corporate income taxes, which together account for nearly half of all tax revenues, have been especially sensitive to the business cycle and have declined significantly in the past two years.

The extent to which states' revenues fall when economic activity declines has been the subject of an extensive literature, much of it focused on general sales taxes and personal income taxes, which together constitute about two-thirds of state tax revenues nationwide. One recent study finds that when state revenues are booming, a 1 percent decline in personal income, on average, causes a drop in sales and income tax revenues far greater than 1 percent in that fiscal year (Bruce, Fox, and Tuttle 2006). For all states that have an income tax, revenues from this tax fall more in response to a 1 percent drop in economic activity than do revenues from sales taxes (2.7 percent as opposed to 1.8 percent).

While these averages across states are revealing, the features of individual states' economies and tax systems can make them more or less responsive to overall changes in economic conditions. For example, states that tax capital gains or whose income tax structures are progressive-including both New York and New Jersey - might be expected to have income tax revenues that are more sensitive to overall economic conditions than are those of other states.

Bruce, Fox, and Tuttle (2006) find modest evidence that supports these propositions. But their research also shows that

\footnotetext{
${ }^{5}$ The chart does not reflect changes in tax rates and structures. On an aggregate level, such changes will generally not be apparent over the course of a business cycle, but they can be quite meaningful for individual states. New Jersey, for example, did not have a personal income tax at the time of the $1973-75$ recession.
}

Chart 1

\section{Aggregate State Tax Revenue Growth}

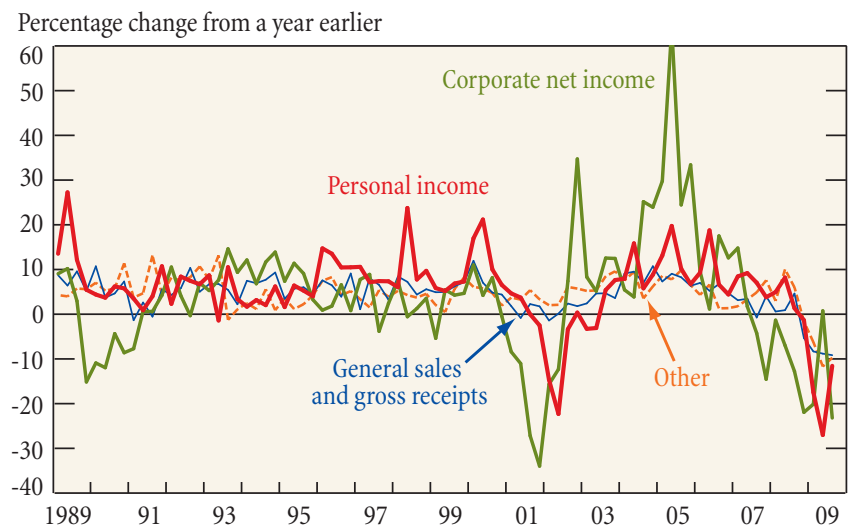

Source: U.S. Department of Commerce, Bureau of the Census, Quarterly Summary of State and Local Tax Revenue.

Note: Corporate net income tax revenues rose 64.1 percent on a year-over-year basis in the second quarter of 2005 .

even though the loss of income tax revenues in New York and New Jersey is not very different from the average, both states are disproportionately dependent on income taxes and, as a result, their aggregate revenues are probably more vulnerable to a downturn. Moreover, in both states, the revenue loss from a one-time drop in income has typically persisted over several fiscal years.

\section{Impact on Expenditures}

The decline in revenues during a recession often coincides with increased demand for state spending. State expenditures from operating budgets typically finance general state operations (mostly public employee compensation), support local governments, and fund various social services. In a downturn, spending on social services-particularly unemployment insurance benefits, welfare, and Medicaid—tends to rise. ${ }^{6}$ Furthermore, reduced rates of return on investments, or even outright losses, can worsen shortfalls in public employee benefit funds, intensifying pressures to step up funding from tax revenues.

Unfortunately, these pressures occur at a time when measures to contain or reduce other forms of public spending - mainly compensation paid to public employees to provide government services - are hard to enact quickly in any substantial way. It is difficult to reduce staff when such cuts can interrupt the delivery

\footnotetext{
${ }^{6}$ Some procurement costs (such as for vendor payments and materials) may drop in a recession as prices fall, but these savings are likely to be relatively small. In some areas, however, recent price declines may have been noticeable. According to Peter Hughes, mayor of Glen Ridge, New Jersey, "The recession has not slowed any of the projects that we are doing to upgrade the borough's infrastructure. In fact, one beneficial result of the recession is that we have realized prices lower than we have anticipated for many of the projects; and in some cases we have been able to do more work than initially planned." See "From the Mayor" in Glen Ridge Town Talk, Autumn 2009, p. 2.
} 
of essential services or leave workers to face a weak private sector job market. Furthermore, workers are resistant to reductions in wage growth. In many instances, layoffs of public employees and cuts in wage levels are subject to union contract terms.

State budgets are also affected by the flow of funds between governments - that is, between the federal government and state governments and between state governments and local (municipal) governments. During recessions, federal grants to state and local governments tend to rise in order to help these entities fund programs such as unemployment insurance or other forms of social welfare. However, the opposite often occurs in the relationship between state governments and local governments. In response to increased pressure on their own budgets, states will frequently try to trim grants to local governments, adding to strains on municipal budgets.

In short, recessions can place great stress on state and municipal budgets. States that rely more heavily on volatile income taxes - New Jersey and New York are prime examples—will face more fiscal stress during economic downturns (Dye and McGuire 1991). In practice, states adjust to cyclical revenue declines in different ways. Poterba (1994) finds that a state's reaction to an unexpected worsening of its finances depends heavily on the nature of its budget rules. States with stringent rules tend to rely more heavily on spending cuts when faced with revenue losses. So given the differences in their budget rules, New York and New Jersey would be expected to respond differently to revenue losses.

\section{The Budgets of New York and New Jersey}

\section{New York}

New York State's budget process starts with the governor overseeing the preparation of a budget that outlines planned receipts and outlays for the coming year, portions of which are items that make up its operating budget, or what New York terms its "general budget." Within the general budget, expenditures cannot exceed revenues. The state legislature modifies the budget and enacts it into law. The governor is also required by state law to manage the budget through administrative actions during the fiscal year (that is, to order spending cuts to close emerging gaps in the general budget).

New York's budget, like those of other states, does not follow the calendar year but the fiscal year, which begins April 1 and ends March 31. Budget preparation begins well in advance; the governor and state legislature review drafts of the upcoming fiscal year's budget in January. ${ }^{7}$

The general budget accounts for less than half of the state's expenditures. In the fiscal year that ended in March 2009,

\footnotetext{
${ }^{7}$ For more on New York's budget process, see http://www.budget.state.ny.us/ citizen/process/process.html.
}

Chart 2

\section{Tax Shares as a Percentage of Total Tax Revenue}
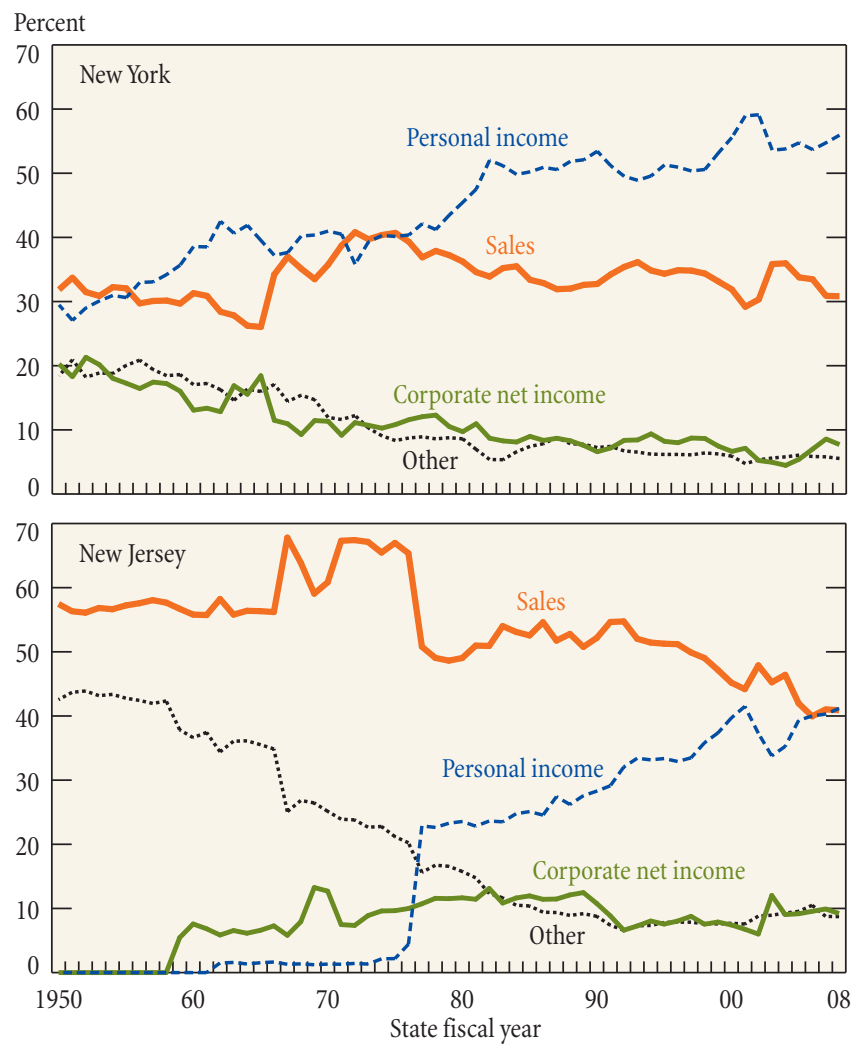

Source: U.S. Department of Commerce, Bureau of the Census, Annual Survey of State Government Finances.

New York's total spending was roughly $\$ 120$ billion. Of this amount, about $\$ 52$ billion was contained in the general budget. The balance of spending by the state and its entities is generally funded either by the federal government ${ }^{8}$ or by public authorities whose spending falls outside the executive budget process. Within the general budget, the state's revenue stream comes primarily from personal income taxes, which account for roughly 55 percent of the monies raised, a share that has been rising steadily in recent decades (Chart 2). Sales taxes and other consumptionrelated taxes and fees contribute another 30 percent, followed by corporate taxes and other taxes, each of which contributes less than 10 percent. Compared with other states, New York is considerably more dependent on cyclically sensitive personal income taxes and business taxes for its revenues.

New York's personal income tax base includes wages, capital gains, interest and dividends, and other sources of income that rise and fall with the tides of the economy. In particular, highincome residents in New York contribute large amounts to state

\footnotetext{
${ }^{8}$ An example of a state-administered program partially funded by the federal government is Medicaid.
} 
Chart 3

\section{State Expenditures by Broad Budget Category Fiscal Year 2009}
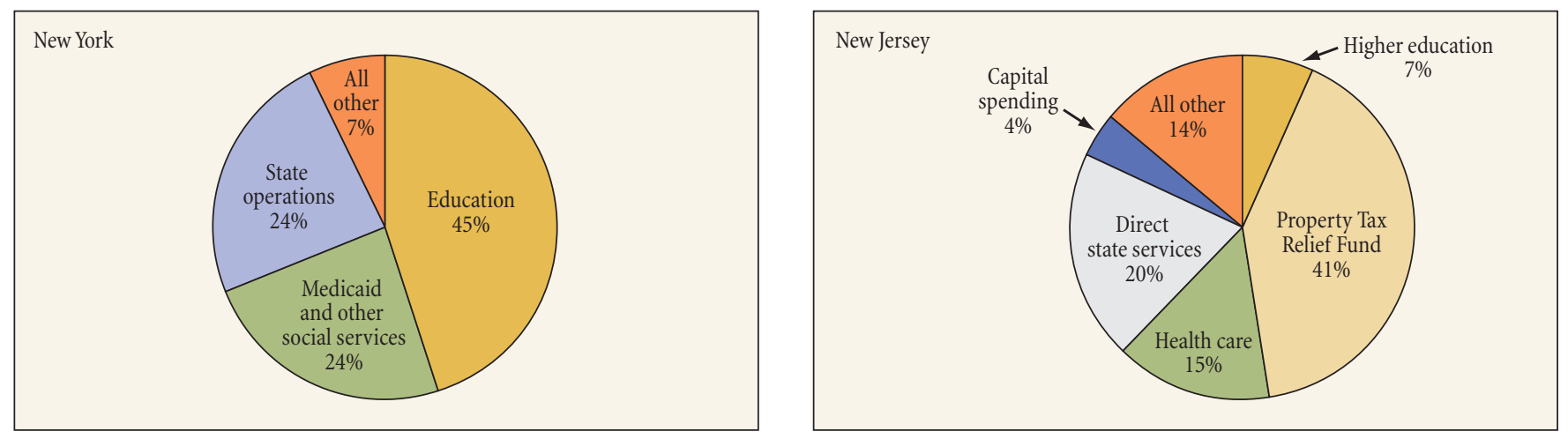

Sources: New York State Office of the Comptroller, Annual Report to the Legislature on State Funds Cash Basis of Accounting, Exhibit A; New Jersey Department of the Treasury; authors' calculations.

Notes: The budget categories for New York and New Jersey do not match because of different accounting methods. The components of New Jersey's expenditures do not sum to 100 percent because of rounding.

coffers, and the 2007-09 recession—with its associated layoffs and capital losses - has placed significant downward pressure on this source of revenue. To understand the sensitivity of the state's revenues to swings in upper-income earnings and capital gains, consider that the top $1 / 2$ of 1 percent of income earners paid about 30 percent of New York State's personal income taxes in fiscal year $2009,{ }^{9}$ while capital gains tax payments from all households accounted for more than one-quarter of all income taxes. A notable share of state income tax receipts comes from Wall Street bonuses, which are estimated to have declined from $\$ 32.9$ billion in 2007 to $\$ 18.4$ billion in 2008 , resulting in a state revenue loss of $\$ 1$ billion in fiscal 2008. ${ }^{10}$

As for expenditures, education and social services account for more than two-thirds of the state's outlays in its general budget (Chart 3). By far the largest component, education constitutes 45 percent of the budget, while Medicaid represents close to 19 percent and other social services almost 6 percent. State operations account for much of the remaining spending. This category includes the operations of various departments, such as the Department of Taxation and Finance and the Department of Labor, and public funding of the State University of New York (SUNY).

A gap of roughly $\$ 16$ billion emerged in New York State's 2010 budget in early 2009, when projected tax revenues were revised

\footnotetext{
${ }^{9}$ See New York State, Division of the Budget (2009, Table 6, "Percent Distribution of Returns, Liability and Adjusted Gross Income by Income Groups under Current Law," p. 200).

${ }^{10}$ See "Wall Street Bonuses Fell 44 Percent in 2008," press release issued by the Office of the New York State Comptroller, January 28, 2009, available at http:// www.osc.state.ny.us/press/releases/jan09/012809.htm.
}

downward as the economy sank deeper into recession. This gap meant that the scale of spending projected, essentially by assuming the maintenance of the earlier legislated level of services, was $\$ 16$ billion greater than anticipated revenues. The adopted budget was brought into balance primarily through tax increases and proceeds from the federal "stimulus bill," or American Recovery and Reinvestment Act (ARRA) of 2009. About half of the gap was closed through tax increases (which included a temporary tax increase on high-wage earners), elimination of the School Tax Relief (STAR) tax rebate for property owners, increases in various fees and licenses, and a SUNY tuition hike. For specific parts of the general budget, federal aid through ARRA covered about $\$ 8$ million, or the other half of the $\$ 16$ billion gap.

In December 2009, the Division of the Budget announced that a $\$ 3$ billion gap remained in the 2010 budget. To deal with this shortfall, the division proposed various legislative and executive actions, including substantial delays in payments to local governments. By early 2010, New York State's prospective budget gap for fiscal 2011 stood at $\$ 7.4$ billion. Governor David Patterson's budget proposed to address this gap with across-the-board cuts in virtually all state agencies and approximately $\$ 1$ billion raised from higher taxes and fees.

In the past, New York has adopted many similar measures to meet budget gaps. Various forms of both temporary and permanent tax increases have been used to raise revenues, primarily through income taxes and sales taxes. For example, in 2003, a temporary income tax surcharge and a temporary sales tax increase were both instituted. The state has also relied on other forms of raising cash that go beyond standard increases in taxes. For example, after the 2001 recession, the state issued bonds 
secured by future tobacco settlement payments - which had been negotiated in the course of settling claims and are scheduled to be received by the state over many years - and used the money raised to help pay for operating expenses. Also at that time, the state ran down some of its built-in reserve funds to help pay for current expenditures.

New York has also moved funds from other parts of its budget to its general budget. For example, independent agencies within the government, such as the New York Power Authority, have turned over excess funds to the state's general budget. And to offset spending, New York increased tuition in its public university system. Many of these actions have been temporary in nature and defer difficult choices to the future (Ravitch 2010).

\section{New Jersey}

New Jersey's constitution requires the legislature to enact a budget for the fiscal year-July 1 to June 30-in which expenditures do not exceed anticipated revenues from taxes and other sources. The governor certifies the revenue projections used to construct the budget. New Jersey's two principal sources of revenue are the personal income tax and the sales tax, which together account for more than three-fourths of state tax revenues (Chart 2).

Like New York, New Jersey depends more on personal income taxes to generate revenue than do most states. The state is also more reliant than most on sales taxes, a relatively stable source of funds. In addition to the $\$ 33.2$ billion in revenue counted in the budget for fiscal year 2008, state entities received more than $\$ 11$ billion in funds from sources outside the regular budget process, roughly three-fourths of which were federal grants-in-aid but also included items such as tuition payments at state colleges.

One unusual feature of New Jersey's tax system is that a large share of the personal income earned by residents consists of wages and salaries earned in, and taxed by, other states; thus, this income is unavailable to New Jersey as a revenue source. ${ }^{11}$ Another feature of note is that both food and clothing purchases are exempt from the sales tax, leaving this revenue source with a narrower base than is typical among states.

Much of the state's revenue stream is constitutionally mandated to fund strictly defined expenditures. Most notably, all personal income tax revenues, as well as a portion of sales tax receipts, are directed into the Property Tax Relief Fund. Outlays from this fund must be used in ways that relieve the burden of local property taxes (in other words, to prevent New Jersey's

\footnotetext{
11 The U.S. Bureau of Economic Analysis (2010) estimates that, in 2009, the difference between personal income earned by New Jersey residents and personal income earned in New Jersey was equal to $\$ 36.6$ billion, or more than 8 percent of the state's personal income. This is by far the highest such dollar figure in the United States. The net share of Maryland's personal income earned outside the state, presumably to a large extent in the District of Columbia, was more than 10 percent; however, the District of Columbia does not levy its local income tax on nonresident workers, meaning that income earned by Maryland residents working in the District can be taxed by Maryland.
}

high property taxes from rising even higher). The monies are primarily disbursed to local school boards, county governments, and municipal governments, as well as to households in the form of direct property tax rebates.

Outside of disbursements from the Property Tax Relief Fund, the state's largest spending category is direct state services, which consists primarily of salaries and benefits for state workers and amounts to one-fifth of the total budget (Chart 3). Health caremostly the state's contribution to Medicaid-is the next largest spending category.

Given the current structure of New Jersey's revenues and expenditures, the state's options for dealing with a large budget gap are rather limited. As noted earlier, all personal income tax receipts (as well as a portion of sales taxes) can be used for only a fairly narrow range of purposes. A hike in the personal income tax can be used to sustain spending on these items, but cannot directly fund other expenditures such as state employee compensation. It is true that other state revenues are also used to help fund the programs financed by the Property Tax Relief Fund. In principle, the more income tax receipts that are available, the less need there would be to devote other tax revenues to the Property Tax Relief Fund. These revenues could then be used for other programs, although the amount that can be shifted in this fashion might be limited.

A move to increase other state taxes presents its own issues. As noted earlier, the sales-tax base is fairly narrow and consists largely of discretionary goods and services; thus a large increase in the sales tax may be needed to raise a substantial sum during a recession. Increases in direct business taxes, such as the state's corporate income tax, may also be insufficient to raise significant amounts of money in slack times. Moreover, increases in either the corporate or personal income tax create a risk of taxpayer flight, especially given the state's small size. ${ }^{12}$

Another potential option for addressing a large budget gap during an economic downturn is to scale back aid to New Jersey's public schools and municipalities. However, large reductions in these programs could put pressure on localities to increase property taxes in order to maintain what are often mandated services. Trimming state spending on state employee compensation and benefits also poses significant challenges. Reducing compensation quickly in a meaningful way while still maintaining overall services would be difficult, and near-term cuts in employee benefit programs could imply the need for enhanced spending in this area in the future. One other approach to bridging a budget gap — cuts in Medicaid, welfare, and other forms of aid to persons - would have the disadvantage of reducing social assistance at the very time such programs were most in demand.

\footnotetext{
${ }^{12} \mathrm{New}$ Jersey has seen an unusually large increase in the out-migration of highnet-worth persons in recent years (Havens 2010).
} 
These general considerations are important to understanding the state's current situation and the policies that have been adopted. At around the time the budget for the 2010 fiscal year was passed, officials projected that, in the absence of legislative changes, revenues from the state's own sources would fall 4.7 percent, from $\$ 28.3$ billion in fiscal 2009 to $\$ 27.3$ billion in fiscal 2010. State expenditures for fiscal 2009 amounted to $\$ 30.2$ billion. Hence, even with no increases in spending, the state faced a gap of about $\$ 3$ billion. ${ }^{13}$

The 2010 state budget addressed this gap by trimming operating costs (achieved by freezing state workers' pay and imposing mandatory furloughs), scaling back property tax rebates, applying for enhanced federal aid, boosting revenue collections through a tax amnesty program, and temporarily raising income taxes. The budget also reduced contributions to employee benefit funds and increased a variety of other taxes and fees. Only the last of these should be expected to have a permanent impact on the state's budget balance.

The steps taken by New Jersey in the 2010 budget are in line with the state's past actions. In episodes of fiscal stress, New Jersey has often closed projected or actual budget gaps without the use of either broad-based tax increases or major cuts in services. For example, in 1991 the state "sold" a short stretch of highway to the New Jersey Turnpike Authority in exchange for several hundred million dollars. And, like New York, New Jersey has issued bonds secured by future tobacco settlement payments and has used the receipts to fund current outlays. In fiscal year 2005 , the state issued $\$ 1.9$ billion in general obligation bonds to cover operating expenses, arguing that the issuance could be viewed as a form of revenue. ${ }^{14}$ These actions, like those used to address the 2010 budget gap, were designed to sustain the state through a temporary downturn in revenues, but did not provide long-term relief from budgetary pressures.

In general, New Jersey has relied a bit more than New York on spending cuts ${ }^{15}$ to deal with budget gaps, in line with the differing budget institutions in the two states. Because of New Jersey's requirement that future revenues cannot fund currentyear spending, state officials probably have more incentive to trim spending in tight times than do their New York counterparts. However, given that New Jersey has tended to experience relatively smaller budget gaps than New York, probably because

\footnotetext{
${ }^{13}$ Some presentations showed a "structural" gap approaching $\$ 9$ billion for fiscal year 2010 (State of New Jersey, Department of the Treasury 2009). However, such calculations were based on the fiscal 2010 "baseline" spending estimate of $\$ 35.7$ billion, rather than on the substantially lower amount of actual spending in the 2009 fiscal year.

14 The New Jersey State Supreme Court approved the move, though it warned that future actions of this type would not necessarily pass judicial review. See New Jersey Supreme Court, Lance v. McGreevey, 180 N.J. 590 (2004).

${ }^{15} \mathrm{~A}$ large portion of these spending cuts have been in the form of reduced contributions to pension funds.
}

\section{Federal Stimulus Funds to New York and New Jersey State Governments}

Billions of Dollars

\begin{tabular}{lcc} 
Category & New York & New Jersey \\
\hline Fiscal relief & 15.9 & 4.0 \\
Medicaid relief & 12.9 & 2.6 \\
Fiscal Stabilization Fund & 3.0 & 1.4 \\
Infrastructure and energy & 3.6 & 1.7 \\
Education and training & 3.4 & 1.0 \\
Health and human services & 5.4 & 3.4 \\
Other & 0.1 & 0.0 \\
$\quad$ Total & 28.3 & 10.1 \\
\hline
\end{tabular}

Sources: Center for American Progress, 2009; authors' calculations.

New Jersey relies less heavily on income taxes for revenue, the scale of the spending cuts in the two states has been more or less comparable.

\section{Challenges Ahead}

When state officials in New York and New Jersey began planning their budgets for the 2011 fiscal year, the continued downgrading of revenue forecasts relative to spending estimates meant that large gaps would need to be addressed. For instance, the administration of New Jersey Governor Chris Christie estimated that state tax revenues in fiscal 2011 would be no larger than those in fiscal 2010. Consequently, if spending were restored to the levels anticipated in past legislation, the result would have been a very large budget gap of roughly $\$ 10.7$ billion. The New Jersey budget adopted in June 2010 addressed this gap largely through reductions in state aid — from already reduced fiscal 2010 levels - to county and local governments and school boards, as well as the deferral of contributions to government employee pension plans. At the time this article was being prepared, New York was still considering its fiscal 2011 budget, so its approach to balancing its budget was not yet clear.

Going forward, New Jersey and especially New York will continue to receive substantial funding from the American Recovery and Reinvestment Act. A large share of the money—about $\$ 140$ billion nationwide - was allocated essentially to provide budgetary relief to states and localities. This figure comprises about $\$ 54$ billion for the State Fiscal Stabilization Fund and an $\$ 87$ billion increase in federal Medicaid funding. The latter increase allows states to substitute federal spending for their own Medicaid contributions.

New York and New Jersey are expected to receive approximately $\$ 16$ billion and $\$ 4$ billion, respectively, in ARRA funding designed specifically to provide budgetary relief. The table above reports these allocations alongside the other stimulus funds 
designated for the two states. ${ }^{16}$ Disbursement of these funds began in 2009 and will continue throughout 2010. The increased Medicaid reimbursement rate, for example, will be available each quarter through the end of $2010 .{ }^{17}$

Although these federal resources are providing welcome relief in the short run, both New York and New Jersey face the risk that this funding, even when combined with recent budget actions, will be insufficient to deal with any revenue shortfalls. Both states may therefore need to trim expenditures substantially to prevent budget deficits. The portion of state budgets subject to balancedbudget requirements suggests that the largest categories for spending cuts would be social services, education, and state operations. However, such reductions could occur at a time when public service needs are particularly acute.

A key challenge for New York and New Jersey will be the alignment of revenues and expenditures after federal aid is scaled back. An optimistic view is that a cyclical upswing will help restore state finances, most visibly by boosting the revenue stream from the financial industry. Such a development would likely be associated with strengthened market values and enhanced returns, which in turn would reduce the need to fund employee retirement plans from tax revenues. An alternative and more troubling view is that the recent suppression of income and revenues from the financial sector will be prolonged (consider that New York State revenues were under strain for most of the 1990s, reflecting an extended Wall Street slump). In this view, budget problems in New York and New Jersey could remain sizable after the federal support fades.

As in many states, Medicaid and public education have put upward pressure on spending in New York and New Jersey, and it seems imprudent to assume that this pressure will ease markedly in the next few years. ${ }^{18}$ Moreover, some of the one-time economies implemented in recent years, such as a deferral of capital spending and reduced contributions to public employee retirement plans, may intensify funding needs in the future. For these reasons, the legislatures and governors of both states could face the painful choice of either making significant cutbacks in services or enacting permanent increases in taxes.

In principle, if the economies of the two states were diversified away from finance, a prolonged slump in that sector would be less worrisome for officials concerned about revenues. However, finance has the advantage of being - and will likely continue to be-a high-income sector. Trading off dependency on a volatile

\footnotetext{
${ }^{16}$ For more details on the national allocation of stimulus funding, see the Center for American Progress website at http://www.americanprogress.org/ issues/2009/02/compromise_map.html.

${ }^{17}$ For more information on particular programs, see http://www.recovery.gov.

${ }^{18}$ Haughwout (2001) discusses trends in New York and New Jersey finances throughout the 1980s and 1990s. Of course, it is possible that some of the proposals to revamp public education, as well as ongoing and potential changes in medical programs, might cause spending pressures in these areas to ease.
}

high-income sector for a more diversified and stable but lowerincome mix of industries would present its own difficulties by reducing a large source of revenue.

In the end, it may be desirable for the states to look into policies that will allow for the continued smooth delivery of services even when revenues - from the finance industry and other sectors-fluctuate sharply. For instance, each state could build a substantial reserve ("rainy day") fund to help insulate it from recession-generated revenue losses and other economic shocks.

To be sure, some studies of reserve funds have argued that the funds are unable to help states manage revenue swings. Gold (1995), for example, contends that in the recession of the early 1990s, most states lacked the political will to maintain rainy day funds large enough to provide a budgetary cushion that would see them through the downturn. However, Douglas and Gaddis (2002), building on work by Sobel and Holcombe (1996), conclude that sufficiently stringent rules can overcome the political disincentives to creating a reserve fund and thereby make the reserve fund option more viable than earlier studies suggested.

Other policy options for New York and New Jersey, and for states in similar positions, might focus on adjusting the composition of revenues to avoid dramatic budget shortfalls. New York and New Jersey are heavily dependent on the highly cyclical personal income tax. One approach to smoothing revenue streams is to reduce reliance on cyclically sensitive tax bases and raise revenues from less volatile sources, notably sales taxes (Sobel and Wagner 2003). Such a strategy would reduce the downward momentum of tax revenues during a recession. However, higher sales taxes would increase burdens on low-income households, who typically come under disproportionate stress during an economic downturn.

Another approach to closing sizable budget gaps like New York's and New Jersey's is to follow a policy rule of temporarily raising income taxes on high-income households during a downturn. The advantage of this approach is that it places a larger burden on households that are less liquidity-constrained than the average household during an economic decline (and less liquidityconstrained than the state itself). Such a tax would be removed once the economy begins to improve. Edgerton, Haughwout, and Rosen (2004) point out that New York City has adopted this balancing strategy in the past, adding temporary surcharges to the top income tax bracket during downturns. ${ }^{19}$

\footnotetext{
${ }^{19}$ For discussions of New York City's budget and how it has fared during the most recent recession, see New York City, Independent Budget Office (2010). Of course, many observers have suggested that New York and New Jersey need to make fundamental changes in the amount and nature of government services they supply, with an eye to bringing down the levels of both taxes and expenditures. But while such proposals may have merit, their adoption alone would not necessarily eliminate cyclical budget gaps, which depend primarily on the behavior of expenditures relative to receipts, not the absolute size of either.
} 
Conceivably, New York and New Jersey, like many other states facing budget difficulties, may ultimately reexamine their budget rules with an eye to clarifying appropriate actions for officials when revenue shocks occur. For example, the states might offer guidelines for choosing which spending areas might be cut, and which taxes might be increased, if the need should arise. In the near term, however, officials in Albany and Trenton will continue to face hard choices in dealing with the immediate realities of shortfalls in revenues and ongoing demands for spending.

\section{References}

Advisory Commission on Intergovernmental Relations. 1987. Fiscal Discipline in the Federal System: National Reform and the Experience of the States, A-107, July.

Bohn, Henning, and Robert Inman. 1996. "Balanced-Budget Rules and Public Deficits: Evidence from the U.S. States." Carnegie-Rochester Series on Public Policy 45, no. 1 (December): 13-76.

Bruce, Donald, William Fox, and M. H. Tuttle. 2006. "Tax Base Elasticities: A Multi-State Analysis of Long-Run and Short-Run Dynamics." Southern Economic Journal 73, no. 2 (October): 315-41.

Douglas, James, and Ronald Keith Gaddis. 2002. "State Rainy Day Funds and Fiscal Crises: Rainy Day Funds and the 1990-1991 Recession Revisited." Public Budgeting and Finance 22, no. 1 (spring): 19-30.

Dye, Richard, and Therese McGuire. 1991. "Growth and Variability of State Individual Income and General Sales Taxes." National Tax Journal 44, no. 1 (March): 55-66.

Edgerton, Jesse, Andrew F. Haughwout, and Rae Rosen. 2004. "Revenue Implications of New York City's Tax System.” Federal Reserve Bank of New York Current Issues in Economics and Finance 10, no. 4 (April).

Gerst, Jeremy, and Daniel Wilson. 2010. "Fiscal Crises of the States: Causes and Consequences." Federal Reserve Bank of San Francisco Economic Letter, no. 2010:20 (June 28).

Gold, Steven, ed. 1995. The Fiscal Crisis of the States. Washington, D.C.: Georgetown University Press.

Haughwout, Andrew F. 2001. "Fiscal Policy in New York and New Jersey: 1977-97." Federal Reserve Bank of New York Current Issues in Economics and Finance 7, no. 7 (July).
Havens, John. 2010."Migration of Wealth in New Jersey and the Impact on Wealth and Philanthropy." Center on Wealth and Philanthropy, Boston College, January 22.

McNichol, Elizabeth, and Nicholas Johnson. 2010. "Recession Continues to Batter State Budgets; State Responses Could Slow Recovery," May 27. Center on Budget and Policy Priorities. Available at http://www.cbpp.org/cms/index $. c f m ? f a=$ view\&id=711 (accessed June 14,2010).

New York City. Independent Budget Office. 2009. “Understanding New York City's Budget: A Guide," September. Available at http://www.ibo.nyc.ny.us/iboreports/ understandingthebudget.pdf.

2010. “Analysis of the Mayor's Preliminary Budget for 2011," March. Available at http://www.ibo.nyc.ny.us/iboreports/march2010final.pdf.

New York State. Division of the Budget. 2009. 2009-10 Executive Budget: Economic and Revenue Outlook. Available at http://www.budget.state.ny.us/ pubs/archive/fy0910archive/eBudget0910/economicRevenueOutlook/ economicRevenueOutlook.pdf.

Poterba, James M. 1994. "State Responses to Fiscal Crises: The Effects of Budgetary Institutions and Politics." Journal of Political Economy 102, no. 4 (August): 799-821.

Ravitch, Richard. 2010. “A Five-Year Plan to Address the New York State Budget Deficit," State of New York, March 10. Available at http://www.state.ny.us/ governor/press/pdf/FIVE\%20YEAR\%20FISCAL\%20PLAN.pdf (accessed May 26, 2010).

Sobel, Russell, and Randall S. Holcombe. 1996."The Impact of State Rainy Day Funds in Easing Fiscal Crises during the 1990-1991 Recession." Public Budgeting and Finance 16, no. 3 (September): 28-48.

Sobel, Russell, and Gary Wagner. 2003. "Cyclical Variability in State Government Revenue: Can Tax Reform Reduce It?” State Tax Notes 29, no. 8 (August 25): 569-76.

State of New Jersey. Department of the Treasury. 2009. FY 2009 - FY 2010

Updates, May 19. Available at http://www.state.nj.us/treasury/omb/ publications/10budget/pdf/fy2010revenuebudgetupdate.pdf.

—. Various years. Budget in Brief. Available at http://www.state.nj.us/ treasury/index.shtml.

U.S. Bureau of Economic Analysis. 2010. "State Personal Income, 2009." Survey of Current Business 90, no. 4 (April): 66-98.

\section{ABOUT THE AUTHORS}

Richard Deitz is a research officer and Andrew F. Haughwout a vice president in the Microeconomic and Regional Studies Function of the Federal Reserve Bank of New York; Charles Steindel is a senior vice president in the Bank's Macroeconomic and Monetary Studies Function.

Current Issues in Economics and Finance is published by the Research and Statistics Group of the Federal Reserve Bank of New York. Linda Goldberg and Charles Steindel are the editors.

Editorial Staff: Valerie LaPorte, Mike De Mott, Michelle Bailer, Karen Carter

Production: Carol Perlmutter, David Rosenberg, Jane Urry

Subscriptions to Current Issues are free. Write to the Media Relations and Public Affairs Department, Federal Reserve Bank of New York, 33 Liberty Street, New York, N.Y. 10045-0001, or send an e-mail to pipubs@ny.frb.org. Back issues of Current Issues are available at http://www.newyorkfed.org/research/current_issues/.

The views expressed in this article are those of the authors and do not necessarily reflect the position of the Federal Reserve Bank of New York or the Federal Reserve System. 


\section{Companion Video Available}

A video interview with the authors of "The Recession's Impact on the State Budgets of New York and New Jersey" is available on the Bank's website, at http://www.newyorkfed.org/aboutthefed/videos.html?bctid=111757963001\&bclid=111857998001. The authors provide additional insights into the genesis of the states' current fiscal difficulties, compare budget strains in New York and New Jersey with those in other states, and assess the outlook for state finances in the period ahead.

\section{FEDERAL RESERVE BANK OF NEW YORK PUBLICATIONS ON RELATED TOPICS}

Other articles in the Current Issues series have addressed recent developments and longer-term structural changes in the

New York-New Jersey region's economy and local revenue systems.

\section{Bypassing the Bust: The Stability of Upstate}

New York's Housing Markets during the Recession

Jaison R. Abel and Richard Deitz

Volume 16, Number 3, March 2010

Over the past decade, the United States has seen real estate activity swing from boom to bust. But upstate New York has been largely insulated from this volatility, with metropolitan areas such as Buffalo, Rochester, and Syracuse even registering home price increases during the recession. An analysis of upstate housing markets over the most recent residential real estate cycle indicates that the region's relatively low incidence of nonprime mortgages and the better-than-average performance of these loans contributed to this stability.

\section{Is the Worst Over? Economic Indexes and} the Course of the Recession in New York and New Jersey

Jason Bram, James Orr, Robert Rich, Rae Rosen, and Joseph Song Volume 15, Number 5, September 2009

The New York-New Jersey region entered a pronounced downturn in 2008, but the pace of decline eased considerably in spring 2009 and then leveled off in July, according to three key Federal Reserve Bank of New York economic indexes. These developments, in conjunction with a growing consensus that the national economy is headed for recovery, suggest that the worst may be over for the region's economy. However, a downsizing of the area's critical finance sector could pose a major risk to the economic outlook going forward-particularly for New York City.
New Measures of Economic Growth and Productivity in Upstate New York

Jaison R. Abel and Richard Deitz

Volume 14, Number 9, December 2008

Newly available measures of GDP at the metropolitan area level now afford a more comprehensive view of regional economic activity. An analysis of upstate New York's economic performance using these measures points to below-average output growth between 2001 and 2006 along with productivity levels and productivity growth below the U.S. average. The region's performance overall, however, is somewhat better than that of many manufacturing-oriented metro areas in the Great Lakes region.

The Price of Land in the New York Metropolitan Area

Andrew F. Haughwout, James Orr, and David Bedoll Volume 14, Number 3, April/May 2008

The price of vacant land in an urban area is a fundamental indicator of an area's attractiveness. However, because the value of vacant land is hard to measure, indirect methods are typically used to gauge prices. A more direct approach to measuring land prices, using a unique data set, reveals that the price of unimproved land in the New York area is high, and rose sharply from 1999 to 2006. The rising trend suggests the underlying strength of the area's economy and the increasing value of the area's productivity and amenities. 


\section{The Foreign-Born Population}

\section{in Upstate New York}

James Orr, Susan Wieler, and Joseph Pereira

Volume 13, Number 9, October 2007

An analysis of upstate New York's foreign-born residents suggests that they contribute to the region's human capital in important ways. This population boasts a greater concentration of college graduates than either the region's native-born population or immigrants downstate. While some immigrants upstate may compete with U.S.-born workers for jobs, the more highly educated appear to be entering skilled occupations-in medicine, science, and research particularly—that complement those of native-born residents.

\section{Evaluating the Relative Strength of the U.S. Capital Markets}

Stavros Peristiani

Volume 13, Number 6, July 2007

Concern is growing that the U.S. capital markets are losing market share to overseas competitors. A decline in foreign initial public offerings indeed suggests that the U.S. equity market is becoming less attractive to certain issuers. However, evidence on the competitiveness of the U.S. equity market is mixed, since the trends affecting it are likewise shaping equity markets abroad. A less ambiguous decline in the share of global issuance can be seen in the U.S. corporate bond market, which is facing a growing challenge from the Eurobond market.

\section{Challenges Facing the New York Metropolitan Area Economy \\ James Orr and Giorgio Topa \\ Volume 12, Number 1, January 2006}

The skilled and well-educated workforce of the New York metropolitan area has played a large role in enabling the region to withstand adverse economic shocks and adapt successfully to a services economy. A further expansion of this "human capital" will enable the metro area to meet the challenges ahead: attracting new firms, maintaining immigration flows, and competing successfully with fast-growing metro areas in other parts of the country.

\section{Revenue Implications of New York City's Tax System \\ Jesse Edgerton, Andrew F. Haughwout, and Rae Rosen Volume 10, Number 4, April 2004}

A study of New York City's tax system finds that over the past three decades, the system has become less reliant on property and general sales taxes and more dependent on corporate and personal income taxes. This shift has made the city's tax revenues less stable than the revenues of the 1970s and more sensitive to cyclical swings.

Fiscal Policy in New York and New Jersey: 1977-97 Andrew F. Haughwout Volume 7, Number 7, July 2001

Between 1977 and 1997, real government spending in New York and New Jersey rose more than 40 percent, led by sharply higher outlays for public welfare and education. Increased tax revenues offset the spending hikes, allowing the states to run large cash surpluses in most years, but both states saw their long-term debt grow markedly. As a result, net financial wealth rose only marginally in New Jersey and declined slightly in New York over the twenty-year period.

\section{Declining Manufacturing Employment in the New York-New Jersey Region: 1969-99 Jason Bram and Michael Anderson Volume 7, Number 1, January 2001}

Between 1969 and 1999, the New York-New Jersey region experienced a steeper drop in manufacturing employment than any other area of the United States. Much of the unusually sharp job decline can be attributed to the geographic dispersion of manufacturing - that is, the gradual movement of manufacturing activity from the more urbanized and industry-intensive states of the Northeast to the less industrially developed states of the South and West. 